\title{
Heavy Metal Tolerance Potential of Aspergillus alliaceus Isolated from a Green Turtle Nesting Site
}

\author{
Esra Deniz CANDAN* \\ Giresun University, Vocational School of Health Services, Department of Medical Services and Techniques, \\ 28100, Giresun, Turkey \\ (ORCID: 0000-0003-2515-9643)
}

\begin{abstract}
Heavy metals are naturally present in the environment. As a result of human activities and some natural events, mixing of these metals in water, air and soil is one of the most serious global problems. The toxicity of these metals is also a serious global problem due to their accumulation in living things and non-biodegradable characteristics. Increasing heavy metal pollution in aquatic and terrestrial environments requires improvement strategies such as bioremediation to remove these metals from the environment for human and environmental health. In this study, fungal isolation was performed to examine fungi with heavy metal remediation potential using sand samples from Sugözü Beaches where are subjected to intense environmental effects due to human activities including industrial facilities and marine traffic. This beach is also an important nesting area for the green turtle. Aspergillus alliaceus isolated from this beach was identified using primers of internal transcribed spacer 1 and 4 . To determine the tolerance of A. alliaceus to iron, zinc, cobalt and copper, the fungus was inoculated into media containing metal at different concentrations $(200,400,600,800$, and $1000 \mathrm{ppm})$. Daily mycelium growths were recorded during a ten day incubation at $30^{\circ} \mathrm{C}$. A.alliaceus was found to tolerate $\mathrm{Fe}$ and $\mathrm{Zn}$ at all concentrations. Besides, it tolerated $\mathrm{Co}$ and $\mathrm{Cu}$ up to 400 and $600 \mathrm{ppm}$, respectively. In this study, the tolerance of A. alliaceus to Fe, $\mathrm{Zn}$, and Co was determined for the first time and it is recommended that it can be used efficiently in bioremediation studies.
\end{abstract}

Keywords: Aspergillus alliaceus, Chelonia mydas, Heavy metal, Metal tolerance.

\section{Yeşil Kaplumbağa Yuvalama Alanından İzole Edilen Aspergillus alliaceus'un Ağır Metal Tolerans Potansiyeli}

\begin{abstract}
$\ddot{O} \mathbf{z}$
Ağır metaller çevrede doğal olarak bulunmaktadır. Bu metallerin insan faaliyetleri ve bazı doğal olaylar sonucunda suya, havaya ve toprağa karışması en ciddi küresel sorunlardan biridir. Bu metallerin toksisitesi, canlılarda birikimi ve biyolojik olarak parçalanamama özellikleri nedeniyle de ciddi bir sorun teşkil etmektedir. Sucul ve karasal ortamlarda giderek artan ağır metal kirliliği; insan ve çevre sağlığı açısından bu metallerin ortamdan uzaklaştırılması için bioremediasyon gibi iyileştirme stratejilerini gerekli kılmaktadır. Bu çalışmada; ağır metal iyileştirme potansiyeline sahip fungusların araştırılması amacıyla endüstriyel tesisler, deniz trafiği gibi insan faaliyetleri nedeniyle yoğun çevresel etkilere maruz kalan Sugözü Kumsalları'ndan alınan toprak örneklerinden fungus izolasyonu gerçekleştirilmiştir. Bu kumsal aynı zamanda yeşil kaplumbağa için önemli bir yuvalama alanıdır. $\mathrm{Bu}$ alandan izole edilen Aspergillus alliaceus, internal transcribed spacer 1 ve 4 primerleri kullanılarak tanımlanmıştır. A. alliaceus'un demir, çinko, kobalt ve bakıra olan toleransının belirlenmesi için; fungus farklı konsantrasyonlarda $(200,400,600,800$ ve $1000 \mathrm{ppm})$ metal içeren besiyerlerine inoküle edilmiştir. $30^{\circ} \mathrm{C}^{\prime} \mathrm{de}$ gerçekleştirilen on günlük inkübasyon süresince günlük olarak misel radyal büyümeleri kaydedilmiştir. Sonuç olarak; A. alliaceus'un Fe ve Zn'yi tüm test konsantrasyonlarında tolere ettiği saptanmıştır. Bunun yanında; kobaltı 600 ppm'e bakırı ise; 400 ppm konsantrasyona kadar tolere ettiği belirlenmiştir. Bu çalışmada; A. alliaceus'un demir, çinko ve kobalt metallerine olan toleransı ilk defa belirlenmiş olup; biyoremediasyon çalışmalarında verimli bir şekilde kullanılabilirliği önerilmektedir.
\end{abstract}

Anahtar kelimeler: Ağır metal, Aspergillus alliaceus, Chelonia mydas, Metal toleransı.

"Corresponding author:esradenizcandan@ gmail.com

Received: 23.11.2020, Accepted: 13.02.2021 


\section{Introduction}

Heavy metals are naturally occurring elements with high atomic weight and density at least five times higher than water [1]. These heavy metals are necessary for plants, animals, and humans to continue their vital activities, but can become toxic in the presence of slightly higher concentrations than recommended level. Industrial, domestic and agricultural wastes, insecticides, pesticides, mining, medical and technological applications, weather conditions, and erosion are important resources that facilitate their entry into the environment $[2,3]$.

Although some heavy metals (e.g., iron) are biologically important to plants and animals, other heavy metals such as lead and chromium without any importance to living organisms can be toxic to organisms when exposed in large amounts or present for a long period $[4,5]$. These toxic effects are associated with various complications in both plants and animals. They can cause a variety of diseases such as mental disorders in children as well as dementia, depression, visual and emotional disorders, cancer, Alzheimer's, Parkinson's, and bone mineralization in adults [6].

Increasing heavy metal pollution in aquatic and terrestrial environments has required improvement strategies such as bioremediation to eradicate these heavy metals from the environment to protect the health of humans and the environment [7, 8]. Traditional methods used for the removal are high-priced and they cause the occurence of certain secondary waste streams. On the other hand, the use of biological agents for heavy metal removal is both easy and environmental-friendly [8]. Regarding the use of fungi, the level of tolerance of fungi to these metals can be quite effective [9, 10]. Metal tolerance or resistance can be defined as the ability of an organism to endure metal toxicity through one or more mechanisms to the metal/metals involved [11]. Therefore, fungi that can tolerate high metal levels (e.g., Aspergillus, Penicillium, Pleurotus, and Trichoderma) have been used as biological tools in bioremediation studies [7, 8, 12-16].

Sugözü Beaches are located, in the north of Iskenderun Bay. This region hosts strategic pipelines (Kirkuk-Yumurtalık and Baku-Tbilisi-Ceyhan) and many organized industrial zones carrying the world's richest oil and gas reserves [17]. This region also contains large quantities of untreated industrial and household wastewater and has one of the most polluted coastal water in Turkey [18]. The fact that the bay is a semi-closed is one of the main reasons that pollutants settle in this area for a long time and the amount of these pollutants increases. One of the major threats to this region is metal pollution. Studies conducted in the region reported that high levels of various toxic metals are released into the marine ecosystem [18-22].

Sugözü Beaches are an important nesting area for Chelonia mydas (the green turtle) [23]. Globally, there is an increasing interest in this endangered (EN) species on the International Union for Conservation of Nature (IUCN) Red List [24]. Pelagic species such as the green turtle can be affected by heavy metal pollution in the surrounding area and accumulate higher levels of heavy metals compared to species nearby the coast $[25,26]$. In addition to monitoringthe pollution levels of marine organisms in the study area, it is important to identify potential biological agents for heavy metal remediation studies in the region. Therefore, this study aims to (I) isolate fungi from sand samples collected from Sugözü Beaches where industrial organizations, marine traffic, and human activities are concentrated; and (II) detect the tolerance of the isolated fungal strain to various heavy metals (i.e., $\mathrm{Fe}, \mathrm{Co}, \mathrm{Cu}$, and $\mathrm{Zn})$.

\section{Materials and Methods}

\subsection{Sample collection}

Sand samples were collected in 2018 from the nesting area of the green turtle on Sugözü Beaches in Adana, Turkey $\left(36^{\circ} 48.677^{\circ} \mathrm{N}, 35^{\circ} 51.068^{\circ} \mathrm{E}\right.$, and $\left.36^{\circ} 52.795^{\prime} \mathrm{N}, 35^{\circ} 56.017^{\prime} \mathrm{E}\right)$. The beaches consist of four subsections: Akkum, Sugözü, Botaş, and Hollanda. The total length of the beaches is $3.4 \mathrm{~km}$. These subsections and surrounding areas are under the pressure of intense human activities, maritime traffic, industry, and agriculture. The area has been recognized as one of the most important nesting sites of the green turtle in the Mediterranean basin [23].

Sand samples were collected and mixed from three different points for each subsection along the nesting site mentioned in previous studies [27]. Sand samples were collected from the top layer of 
the sand profile $(0-30 \mathrm{~cm})$ after the removal of the surface. Sand samples were collected in pre-cleaned, sterilized polyethylene bottles $(2 \mathrm{~L})$, and plastic zipper bags. The samples were transported to a laboratory in ice bags $\left(4^{\circ} \mathrm{C}\right)$.

\subsection{Isolation and identification of fungal strains}

Serial dilution and standard spreading techniques were applied to isolate fungi from the sand samples. Samples with different concentrations were added to the Sabouraud Dextrose Agar (SDA) (HiMedia, Mumbai) medium. After the cultivation, cultures were incubated at $30^{\circ} \mathrm{C}$ for one week. Pure cultures obtained by serial passaging were kept at $4^{\circ} \mathrm{C}$ and used as stock cultures.

Genomic DNA samples were extracted using the EurX Gene MATRIX Plant \& Fungi DNA isolation kit (Poland) and DNA fragments containing internal transcribed spacers ITS 1 and ITS 4 (ITS15'TCCGTAGGTGAACCTGCGG3' and ITS4 5'TCCTCCGCTTATTGATATGC3') were amplified using Kyratec Thermal Cycler (Australia) [28]. Amplification reactions were performed in $35 \mu \mathrm{L}$ of reaction that contained $4 \mu \mathrm{L}$ of template DNA, $1.5 \mathrm{mM} \mathrm{MgCl}_{2}, 0.2 \mathrm{mM}$ dNTP, $2 \mathrm{U}_{\text {FIREPol }}{ }^{\circledR}$ DNA Polymerase (Solis BioDyne, Estonia), $1 \times$ PCR Buffer Solis BioDyne, and $0.3 \mu \mathrm{M}$ of each primer. The following amplification program was applied: an initial denaturation step at $95^{\circ} \mathrm{C}$ for 5 minutes, followed by 40 cycles of denaturation at $95^{\circ} \mathrm{C}$ for $45 \mathrm{~s}$, annealing at $57^{\circ} \mathrm{C}$ for $45 \mathrm{~s}$, and extension at $72^{\circ} \mathrm{C}$ for $60 \mathrm{~s}$. Amplification was terminated after a final extension of $72^{\circ} \mathrm{C}$ for 5 minutes.

Sequencing of samples was performed using ABI 3730XL automatic sequencer (Applied Biosystems, USA) by Macrogen, Inc. (Seoul, Korea). The sequences were assembled and edited using the Contig Assembly Program (CAP) option in the BioEdit software version 7.0.9.1. The sequences were compared to the GenBank database through the National Centre for Biotechnology Information (NCBI) nucleotide databases using BLAST.

\subsection{Heavy metal tolerance assay}

Different concentrations of metal solutions (i.e., 200, 400, 600, 800, and $1000 \mathrm{ppm})\left(\mathrm{FeCl}_{2}, \mathrm{CoCl}_{2}\right.$, $\mathrm{CuCl}_{2} \cdot 2 \mathrm{H}_{2} \mathrm{O}$, and $\mathrm{ZnCl}_{2}$ ) were separately added to SDA medium to examine heavy metal tolerance. The medium was sterilized in an autoclave at $121{ }^{\circ} \mathrm{C}$ for 15 minutes. After the sterilization, the mediumwas removed from the autoclave, allowed to cool to $50^{\circ} \mathrm{C}$, and then poured into Petri dishes and allowed to solidify.

Mycelium growths of the fungal strain were subjected to a range of $\mathrm{Cu}, \mathrm{Co}, \mathrm{Fe}$, and $\mathrm{Zn}$ concentrations (0-1000 ppm) incorporated to SDA in triplicates. Fungal radial growths were recorded every day over a 10-day-incubation period. Seven-day old pure fungal cultures were individually inoculated into an $8 \mathrm{~mm}$ well aseptically punched in the center of the control and test SDA plates. All plates were incubated at $30^{\circ} \mathrm{C}$ for 10 days when the mycelial radial growths were monitored and recorded daily.

\section{Results and Discussion}

The use of microorganisms in the remediation of heavy metal contaminated soils is an environmentalfriendly approach $[8,15]$. Moreover, the adsorption capacity of some fungal biomass in the removal of metal ions ensures the use of these fungi as biosorbents [8]. The level of heavy metal tolerance can be very effective in assessing the use of fungi as biosorbents $[9,10]$. Therefore, in this study, the fungus sample was isolated from green turtle nesting beaches where industrial facilities, marine traffic, and human activities are intense; and the heavy metal tolerance of this fungus was assessed.

\subsection{Identification of the fungal strain}

Identification of the fungus isolated from sand samples in the nesting area was achieved based on the ITS 1 and ITS 4 regions. ITS region sequences homologous to other isolates have been identified using the GenBank database. The fungal strain identified in the study was closely related to the Aspergillus alliaceus MH279440.1 strain in the Eurotiomycetes class (ITS identity, 100\%). Previous studies also reported that Aspergillus species are isolated in heavy metal contaminated areas [11, 16, 29]. The 
presence of this type of fungi in polluted environments is based on their ability to survive in extreme conditions and metabolize various substrates as food source [14, 30, 31].

\subsection{Radial growth of the fungal strain at various heavy metal concentrations}

Mycelium growth in A. alliaceus strain in SDA medium containing different concentrations (0-1000 $\mathrm{ppm})$ of $\mathrm{Cu}, \mathrm{Co}, \mathrm{Fe}$, and $\mathrm{Zn}$ is presented in Figure 1. A. alliaceus tolerated $\mathrm{Fe}$ and $\mathrm{Zn}$ at all concentrations (0-1000 ppm). In addition, it can tolerate $\mathrm{Co}$ and $\mathrm{Cu}$ up to 600 and $400 \mathrm{ppm}$, respectively (Figure 1).
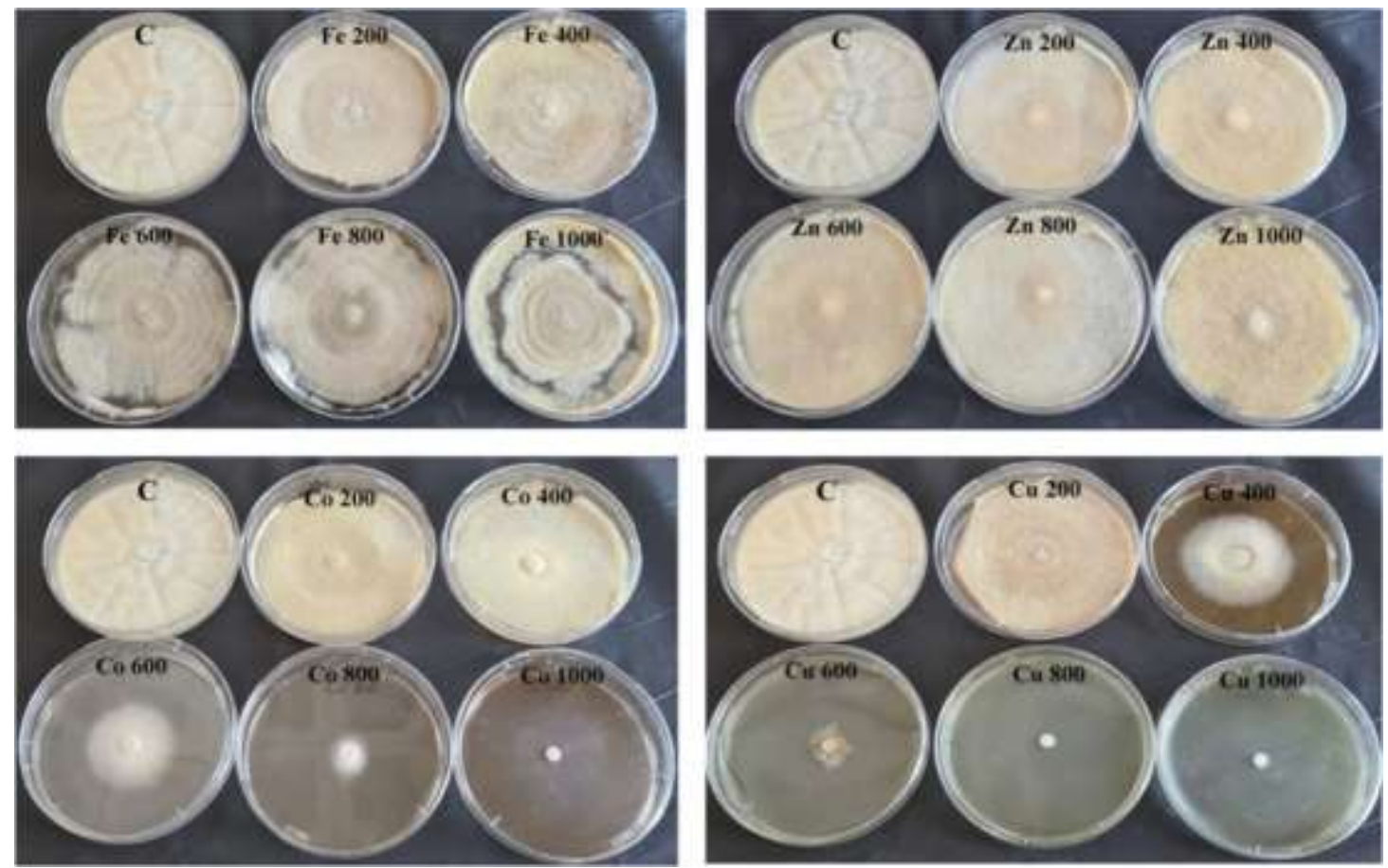

Figure 1. Growth of A.alliaceus at various concentrations (0-1000 ppm) of $\mathrm{Fe}, \mathrm{Zn}, \mathrm{Co}$, and $\mathrm{Cu}$ for 10 days (C: Control).

Daily mycelium growth of A. alliaceus during the incubation period of $\mathrm{Fe}, \mathrm{Zn}, \mathrm{Co}$, and $\mathrm{Cu}$ at different concentrations is presented in Figure 2. Although A. alliaceus expressed a high tolerance for $\mathrm{Fe}$ and $\mathrm{Zn}$, it expressed a weaker tolerance for $\mathrm{Co}$ and $\mathrm{Cu}$ compared to other heavy metals.

Living organisms need to acquire heavy metals such as $\mathrm{Fe}, \mathrm{Co}$, and $\mathrm{Cu}$ in low quantities to survive. However, uptake of these metals in high concentrations can be harmful. Zinc is known as one of the heavy metals that pollute the environment and adversely affect public health $[32,33]$. In this study, the high tolerance level of A. alliaceus to $\mathrm{Fe}$ and $\mathrm{Zn}$ is one of the most important indicators of the presence of $\mathrm{Fe}$ and $\mathrm{Zn}$ in the environment where the fungus was isolated. Moreover, $\mathrm{Fe}$ and $\mathrm{Zn}$ values were high in biota, seawater, and sediment samples in Iskenderun Bay, and strong positive relationships were also detected between these values [21]. These metals are highly accumulated in the muscles and liver of fish [21]. Also, many studies observed various toxic effects of these metals on aquatic and terrestrial ecosystems $[34,35]$.

In this study, A. alliaceus was found to have a certain tolerance to $\mathrm{Cu}$ and $\mathrm{Co}$ (Figure 1). In an analysis of $\mathrm{Fe}, \mathrm{Cu}, \mathrm{Ni}, \mathrm{Cr}$, and $\mathrm{Zn}$ in fish tissues (muscle, skin, and gonad) collected from different stations [18], heavy metal levels were higher at the station (Yumurtalık) close to Sugözü Beaches compared to other stations. Annual mean heavy metal accumulation levels in the stone samples taken from Iskenderun Bay were determined as $\mathrm{Al}>\mathrm{Fe}>\mathrm{Zn}>\mathrm{Pb}>\mathrm{Cu}>\mathrm{Cd}>\mathrm{Mn}>\mathrm{Ni}>\mathrm{Co}>\mathrm{Cr}$ [22]. Based on these values, it is apparent that both terrestrial and aquatic ecosystems in the region have been exposed to heavy metals. In another study in the region conducted to evaluate negative consequences of excessive pollution caused by industrial and commercial activities, high concentrations of $\mathrm{Hg}, \mathrm{Cd}, \mathrm{Zn}$, and $\mathrm{Pb}$ were detected in the surface sediment in water; $\mathrm{Al}, \mathrm{Cr}, \mathrm{Fe}, \mathrm{Li}, \mathrm{Ni}, \mathrm{Mn}, \mathrm{Mg}, \mathrm{Pb}$, and $\mathrm{Zn}$ were reported in the soil and therefore, heavy metal diversity in the region has been indicated [17]. 
Microbial bioremediation is a method in which microorganisms are used to decompose environmental pollutants and convert them into harmless forms by redox processes. The tolerance level of fungi to these pollutants is quite important to use fungi as biosorbents in this method $[9,10]$. Particularly, fungi isolated from contaminated areas express higher tolerance than other fungi $[7,14,36$, 37].

Based on the heavy metal tolerance of A. alliaceus isolated and identified in this study, A. alliaceus could be suggested as a potential biological tool to improve the environmental quality. The tolerance of A. alliaceus isolated from $\mathrm{Fe}-\mathrm{Cu}$ sulfur mines was $200 \mathrm{ppm}$, and there was no growth at $400 \mathrm{ppm}$ [7]. In this study, the tolerance level for copper metal was found to be higher. Besides, the tolerance level of $A$. alliaceus to heavy metals (except for $\mathrm{Cu}$ ) has been reported for the first time by this study.
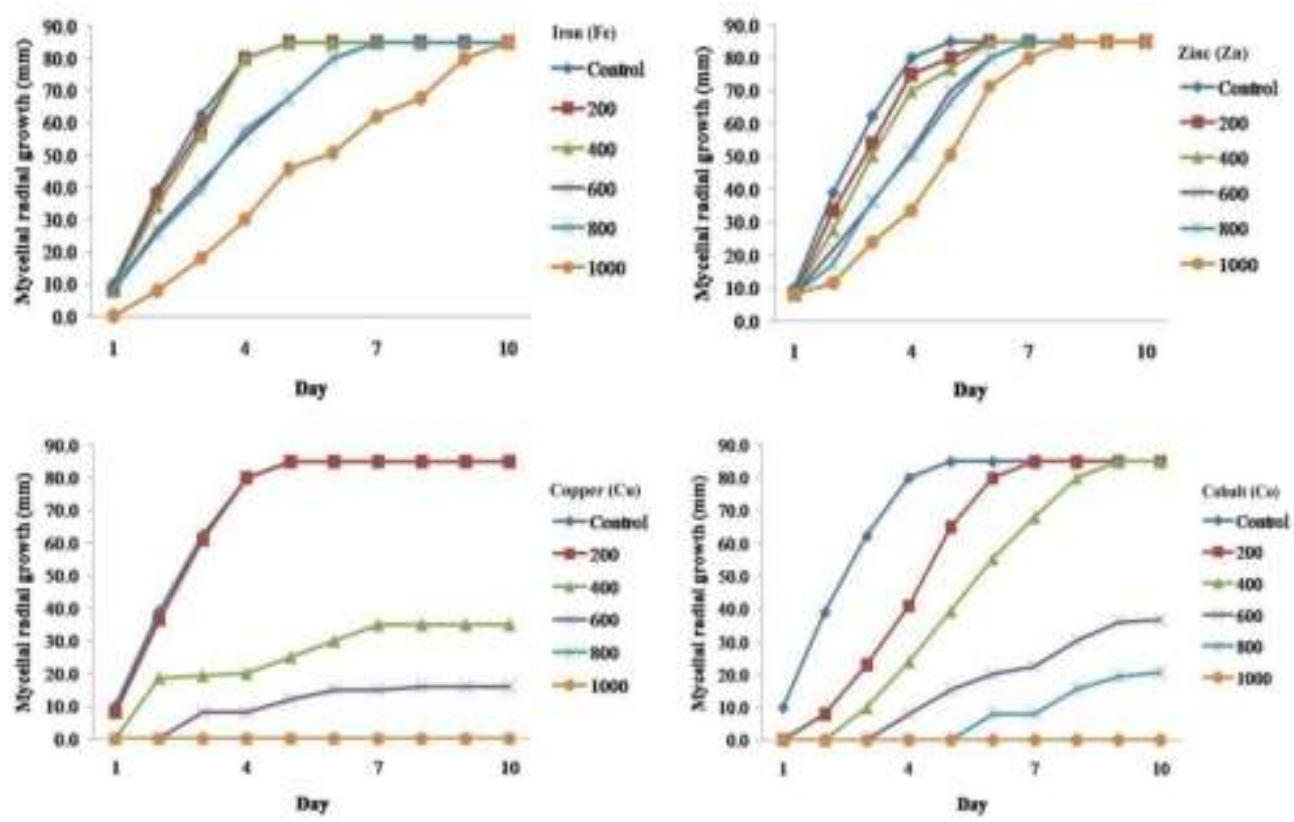

Figure 2. Radial growth of the mycelium (mm) in A. alliaceus at various concentrations of Fe, $\mathrm{Zn}, \mathrm{Co}$, and $\mathrm{Cu}$ for 10 days.

\section{Conclusion}

Metal pollutants in terrestrial and aquatic ecosystems dissolve either in the soil or water and subsequently accumulate on the seafloor. These metals can be taken by terrestrial or aquatic organisms while accumulation continues. Gradual and irreversible accumulation of these metals in various organs of marine organisms and their toxicity cause metal-related diseases in the long term, threatening both other organisms and aquatic ecosystems. The study area is exposed to intense environmental impacts due to agricultural activities, industrial facilities, local settlements, river discharges, transportation, and directly affected by marine pollution. Fungus-based bioremediation is a cheaper and more environmentally friendly method than existing traditional methods to remove heavy metal wastes from the field. Therefore, the high resistance of $A$. alliaceus to $\mathrm{Fe}, \mathrm{Zn}, \mathrm{Co}$, and $\mathrm{Cu}$ has been determined in this study. Additionally, the tolerance of A. alliaceus to $\mathrm{Fe}, \mathrm{Zn}$, Co was determined for the first time with this study, and it was suggested to be used efficiently in bioremediation studies. This study can also make a significant contribution to the development of bioremediation studies to remove heavy metals that threaten both Sugözü Beaches and the green turtle using the area as a nesting beach.

\section{Acknowledgements}

In this study; "identification of fungal strain" was funded by Giresun University Scientific Researches Project Coordination Department (FEN-BAP-A-150219-11). I thank Onur CANDAN, PhD., for 
comments on the earlier version of this manuscript and Fatih FAZLIOĞLU, PhD. for linguistic advice and criticism.

\section{Author's Contributions}

All contributions belong to the author in this paper.

\section{Statement of Conflicts of Interest}

There is no conflict of interest among the authors.

\section{Statement of Research and Publication Ethics}

The author declares that this study complies with Research and Publication Ethics. None of the experiments involved here sacrifice animals and therefore, approval from an institutional animal research ethics committee is not required.

\section{References}

[1] Järup L. 2003. Hazards of Heavy Metal Contamination. British Medical Bulletin, 68 (1): 167182.

[2] Morais S., Costa F.G., Pereira M.D.L. 2012. Heavy Metals and Human Health. Environmental Health-Emerging Issues and Practice, 10: 227-246.

[3] Tchounwou P.B., Yedjou C.G., Patlolla A.K., Sutton D.J. 2012. Heavy Metal Toxicity and the Environment. In: Molecular, Clinical and Environmental Toxicology, Edited by Luch A., Vol: 5, Experientia Supplementum, Springer, Basel, 133-164.

[4] Duruibe J.O., Ogwuegbu M.O.C., Egwurugwu J.N. 2007. Heavy Metal Pollution and Human Biotoxic Effects. International Journal of Physical Sciences, 2 (5): 112-118.

[5] Rehman A.U., Nazir S., Irshad R., Tahir K., urRehman K., Islam R.U., Wahab Z. 2020. Toxicity of Heavy Metals in Plants and Animals and Their Uptake by Magnetic Iron Oxide Nanoparticles. Journal of Molecular Liquids, 114455.

[6] Jan A.T., Azam M., Siddiqui K., Ali A., Choi I., Haq Q.M. 2015. Heavy Metals and Human Health: Mechanistic Insight into Toxicity and Counter Defense System of Antioxidants. International Journal of Molecular Sciences, 16 (12): 29592-29630.

[7] Zotti M., Di Piazza S., Roccotiello E., Lucchetti G., Mariotti M.G., Marescotti P. 2014. Microfungi in Highly Copper-Contaminated Soils from an Abandoned $\mathrm{Fe}-\mathrm{Cu}$ Sulphide Mine: Growth Responses, Tolerance and Bioaccumulation. Chemosphere, 117: 471-476.

[8] Jacob J.M., Karthik C., Saratale R.G., Kumar S.S., Prabakar D., Kadirvelu K., Pugazhendhi A. 2018. Biological Approaches to Tackle Heavy Metal Pollution: A Survey of Literature. Journal of Environmental Management, 217: 56-70.

[9] Carrillo-González R., González-Chávez M.D.C.A. 2012. Tolerance to and Accumulation of Cadmium by the Mycelium of the Fungi Scleroderma citrinum and Pisolithustinctorius. Biological Trace Element Research, 146 (3): 388-395.

[10] Ceci A., Maggi O., Pinzari F., Persiani A.M. 2012. Growth Responses to and Accumulation of Vanadium in Agricultural Soil Fungi. Applied Soil Ecology, 58: 1-11.

[11] Zafar S., Aqil F., Ahmad I. 2007. Metal Tolerance and Biosorption Potential of Filamentous Fungi Isolated from Metal Contaminated Agricultural Soil. Bioresource Technology, 98 (13): 25572561.

[12] Valix M., Tang J.Y., Malik R. 2001. Heavy Metal Tolerance of Fungi. Minerals Engineering, 14 (5): 499-505.

[13] Anahid S., Yaghmaei S., Ghobadinejad Z. 2011. Heavy Metal Tolerance of Fungi. ScientiaIranica, 18 (3): 502-508.

[14] Iskandar N.L., Zainudin N.A.I.M., Tan S.G. 2011. Tolerance and Biosorption of Copper (Cu) and Lead $(\mathrm{Pb})$ by Filamentous Fungi Isolated from a Freshwater Ecosystem. Journal of Environmental Sciences, 23 (5): 824-830. 
[15] Ojuederie O.B., Babalola O.O. 2017. Microbial and Plant-Assisted Bioremediation of Heavy Metal Polluted Environments: A Review. International Journal of Environmental Research and Public Health, 14 (12): 1504.

[16] Rose P.K., Devi R. 2018. Heavy Metal Tolerance and Adaptability Assessment of Indigenous Filamentous Fungi Isolated from Industrial Wastewater and Sludge Samples. Beni-Suef University Journal of Basic and Applied Sciences, 7 (4): 688-694.

[17] Doygun H., Alphan H. 2006. Monitoring Urbanization of Iskenderun, Turkey, and Its Negative Implications. Environmental Monitoring and Assessment, 114 (1-3): 145-155.

[18] Yilmaz A.B. 2003. Levels of Heavy Metals (Fe, Cu, Ni, Cr, Pb, And $\mathrm{Zn}$ ) in Tissue of Mugil cephalus and Trachurus mediterraneus from Iskenderun Bay, Turkey. Environmental Research, 92 (3): 277-281.

[19] Cevik U., Koz B., Makarovska Y. 2010. Heavy Metal Analysis Around Iskenderun Bay in Turkey. X-Ray Spectrometry: An International Journal, 39 (3): 202-207.

[20] Yilmaz A.B., Sangün M.K., Yağlıoğlu D., Turan C. 2010. Metals (Major, Essential to NonEssential) Composition of The Different Tissues of Three Demersal Fish Species from Iskenderun Bay, Turkey. Food Chemistry, 123 (2): 410-415.

[21] Çiftçi N., Ayas D., Bakan M. 2020. The Comparison of Heavy Metal Level in Surface Water, Sediment and Biota Sampled from the Polluted and Unpolluted Sites in the Northeastern Mediterranean Sea. Thalassas: An International Journal of Marine Sciences, 1-12.

[22] Duysak Ö., Uğurlu E. 2020. Trace Metal Concentrations in the Seston of the Gulf of İskenderun (Turkey, North-Eastern Mediterranean). Thalassas: An International Journal of Marine Sciences, 36 (1): $125-132$.

[23] Canbolat A.F., Atatunç K., Candan O., Barcak D. 2005. A New Green Turtle (Chelonia mydas) Nesting Site in The Mediterranean: Sugözü Beaches, Adana (Turkey). The Second Mediterranean Conference on Sea Turtles, Book of Abstracts, 4-7 May, Antalya, 65.

[24] Seminoff J.A. 2004. Chelonia mydas. The IUCN Red List of Threatened Species 2004: e. T4615A11037468.

[25] Anan Y., Kunito T., Sakai H., Tanabe S. 2002. Subcellular Distribution of Trace Elements in The Liver of Sea Turtles. Marine Pollution Bulletin, 45 (1-12): 224-229.

[26] Sinaei M., Bolouki M. 2017. Metals in Blood and Eggs of Green Sea Turtles (Chelonia mydas) from Nesting Colonies of the Northern Coast of the Sea of Oman. Archives of Environmental Contamination and Toxicology, 73 (4): 552-561.

[27] Candan O., Candan E.D. 2020. Bacterial Diversity of the Green Turtle (Chelonia mydas) Nest Environment. Science of The Total Environment, 720: 137717.

[28] White T.J., Bruns T., Lee S.J.W.T., Taylor J. 1990. Amplification and Direct Sequencing of Fungal Ribosomal RNA Genes for Phylogenetics. PCR protocols: A guide to methods and Applications, 18 (1): 315-322.

[29] Oladipo O.G., Awotoye O.O., Olayinka A., Ezeokoli O.T., Maboeta M.S., Bezuidenhout C.C. 2016. Heavy Metal Tolerance Potential of Aspergillus Strains Isolated from Mining Sites. Bioremediation Journal, 20 (4): 287-297.

[30] Gavrilescu M. 2004. Removal of Heavy Metals from the Environment by Biosorption. Engineering in Life Sciences, 4 (3): 219-232.

[31] Mukherjee A., Das D., Mondal S.K., Biswas R., Das T.K., Boujedaini N., Khuda-Bukhsh A.R. 2010. Tolerance of Arsenate-Induced Stress in Aspergillus niger, A Possible Candidate for Bioremediation. Ecotoxicology and Environmental Safety, 73 (2): 172-182.

[32] Tchounwou P.B., Newsome C., Williams J., Glass K. 2008. Copper-induced cytotoxicity and transcriptional activation of stress genes in human liver carcinoma (HepG2) cells. Metal Ions in Biology and Medicine, 10: 285-290.

[33] Kushwaha A., Rani R., Kumar S., Gautam A. 2015. Heavy Metal Detoxification and Tolerance Mechanisms in Plants: Implications for Phytoremediation. Environmental Reviews, 24 (1): 3951.

[34] Vuori K.M. 1995. Direct and indirect effects of iron on river ecosystems. In Annales Zoologici Fennici, 32: 317-329. 
[35] McKinley K., McLellan I., Gagné F., Quinn B. 2019. The Toxicity of Potentially Toxic Elements $(\mathrm{Cu}, \mathrm{Fe}, \mathrm{Mn}, \mathrm{Zn}$ and $\mathrm{Ni}$ ) to the Cnidarian Hydra attenuata at Environmentally Relevant Concentrations. Science of the Total Environment, 665: 848-854.

[36] Muñoz A.J., Ruiz E., Abriouel H., Gálvez A., Ezzouhri L., Lairini K., Espínola F. 2012. Heavy Metal Tolerance of Microorganisms Isolated from Wastewaters: Identification and Evaluation of Its Potential for Biosorption. Chemical Engineering Journal, 210: 325-332.

[37] Iram S., Zaman A., Iqbal Z., Shabbir R. 2013. Heavy Metal Tolerance of Fungus Isolated from Soil Contaminated with Sewage and Industrial Wastewater. Polish Journal of Environmental Studies, 22: 3 . 